\title{
Vegetation structure and floristic composition of tree species in the habitat of Scaphium macropodum in Gunung Leuser National Park, Sumatra, Indonesia
}

\author{
ARIDA SUSILOWATI ${ }^{1, \bullet}$, DENI ELFIATI ${ }^{1}$, HENTI HENDALSTUTI RACHMAT ${ }^{2}$, KUSUMADEWI SRI YULITA ${ }^{3}$, \\ ADI NURUL HADI ${ }^{4}$, YOSIE SYADZA KUSUMA ${ }^{5}$, SRI ANJELI LUMBAN BATU ${ }^{1}$ \\ ${ }^{1}$ Faculty of Forestry, Universitas Sumatera Utara. Jl. Tri Dharma Ujung No. 1, Kampus USU, Medan 20155, North Sumatra, Indonesia. \\ Tel./fax.:+62-61-820-1920, `email: arida_iswanto@yahoo.co.id; arida.susilowati@usu.ac.id \\ ${ }^{2}$ Forest Research and Development Center, Ministry of Environment and Forestry. Jl. Raya Gunung Batu, Bogor 16118, West Java, Indonesia \\ ${ }^{3}$ Research Center for Biology, Indonesian Institutes of Sciences. Jl. Raya Bogo Km. 46, Cibinong, Bogor 16911. West Java, Indonesia \\ ${ }^{4}$ Gunung Leuser National Park, Ministry of Environment and Forestry. Jl. Selamat No. 137, Medan 20219, North Sumatra, Indonesia \\ ${ }^{5}$ Tropical Silviculture Program, School of Graduates, Institut Pertanian Bogor. Jl. Raya Dramaga, Bogor 16680, West Java, Indonesia
}

Manuscript received: 2 June 2020. Revision accepted: 12 June 2020.

\begin{abstract}
Susilowati A, Elfiati D, Rachmat HH, Yulita KS, Hadi AN, Kusuma YS, Batu SAL. 2020. Vegetation structure and floristic composition of tree species in the habitat of Scaphium macropodum in Gunung Leuser National Park, Sumatra, Indonesia. Biodiversitas 21: 3025-3033. Scaphium macropodum (Miq.) Beumee Ex K Heyne is a member of Malvaceae tree species and globally recognized as malva nut and locally known as 'kembang semangkok', 'tempayang', 'merpayang' or 'kepayang'. The nut of $S$. macropodum has many benefits for medicinal purposes, yet destructive extraction of this tree species has led them to extinction. Among its natural distribution in Indonesia, North Sumatra Province, Indonesia is known as its original range, but there is limited information about the existence of this species. This study aimed to determine the vegetation structure of some tree species in the habitat of S. macropodum in Sikundur, Gunung Leuser National Park, Sumatra, Indonesia. Purposive sampling technique was employed by creating line transect at some forest areas where the population of $S$. macropodum is known to grow naturally. Four line transects with each transect consisting of five plots with nested plots within were established to record data at four growth stages, resulting in 80 plots in total. The results showed that the Important Value Index (IVI) of S. macropodum within the floristic community at the studied area was 21.98, 13.85, 27.30, and 39.60 for tree, pole, sapling, and seedlings stages, respectively. The Shannon-Wiener Diversity Index $(\mathrm{H})$ were 3.80, 3.70, 3.06 and 2.45, Index of evenness $(\mathrm{E})$ are 0.94, 0.92, 0.86, 0.77 and the Index of Richness (R) are $11.76,10.73,6.59,4.10$ for tree, pole, sapling, and seedlings stages. This result suggests that the natural population of $S$. macropodum in Sikundur forest was still in good condition at all stages from tree to seedling.
\end{abstract}

Keywords: Diversity, growth stage, kembang semangkok, species, structure vegetation

\section{INTRODUCTION}

Scaphium is a member of tree genus with large canopy with height that can reach up to $40 \mathrm{~m}$ and diameter at breast height is usually $10-40 \mathrm{~cm}$ (Wilkie 2009). There are eight species from Scaphium genera distributed in Southeast Asia region from Burma, through Thailand, Cambodia, Malaysia, Singapore, Sumatra, and Bangka to Borneo (Yamada et al. 2000). One of Scaphium species that grows naturally in Indonesia is Scaphium macropodum (Miq.) Beumee Ex K Heyne (Yamada et al. 1999). S. macropodum is distributed in Myanmar, Cambodia, Laos, Vietnam, Thailand, Peninsular Malaysia, Sumatra, and Borneo (Lim 2012). S. macropodum, locally known as 'kembang semangkok', 'tempayang', 'merpayang', 'kepayang' or malva nut, is a wild tree species and is known as one of important non-timber forest products that supports the livelihoods of community living around forest (Bann 1997). The high demand for its seeds for traditional and pharmacological uses together with the lack of cultivation efforts, has reduced the species population, putting them as least concern category according to IUCN
Red-list (World Conservation Monitoring Center 1998).

According to Lim (2012), S. macropodum is well known to have medicinal properties. Both in vitro and in vivo studies demonstrate that this species exhibits a variety of pharmacological activities, including antihypertensive, antimicrobial, analgesic, anti-inflammatory, antipyretic, weight-losing and laxative (Ai et al. 2012; Li 2015; Ogale et al. 2015; Dhange et al. 2015;). In Vietnam, the fruits of $S$. macropodum are widely used for tonic and medicinal beverages (Huy et al. 2012). When its nuts soaked in water it will produce large amounts of gelatin, which is used as a medicine to cure intestinal infections, diarrhea, sore throat, asthma, dysentery, fever, cough, inflammation, and urinary tract diseases. Some people drink malva nut juice for dieting purposes because it has cool feels and can break fever. In Java, malva nut is mixed with cinnamon and basil to treat thrush and cough. Mixing malva nut with bitter aloe and Vitex pteropod seeds is commonly used to cure dysentery (Phonsena and Wilkie 2008).

Among S. macropodum natural distribution in Sumatra, Batangtoru, and Gunung Leuser National Park (GLNP) are found as the natural habitat of the species (Sambas and 
Siregar 2017). GNLP is a conservation area where exploitation and land-use change are strictly prohibited by laws, however, there are some illegal activities performed by community, for example, timber cutting for construction materials and fuelwood collection. Due to these activities, the forest ecosystem in GLNP has been experiencing decreasing number in tree species and stands, resulting changes in species composition. Similar trends may occur to $S$. macropodum population which can change their sustainability in the future.

Analysis on vegetation composition and structure in a habitat enables to reveal the status and quality of a forest community by quantifying the existence of tree species at each growing stage and also observed the threat and possible conservation effort to conduct in the future (Rachmat et al. 2018; Susilowati et al. 2019). Vegetation structure is also highly determined by habitat characteristics, species diversity, and regeneration status of a species (Dutta and Devi 2013). Vegetation studies are important in order to provide basic data to formulate conservation strategies and species management, especially the species that have high levels of vulnerability. Thus, this study is conducted to determine the vegetation structure of some tree species in the habitat of $S$. macropodum in Gunung Leuser National Park, Sumatra, Indonesia. This information is important, since the data on population and distribution of S. macropodum in its natural distribution of North Sumatra is still limited despite their widely known benefits to support the sustainability of this species in the future.

\section{MATERIALS AND METHODS}

\section{Study period and location}

The data collection and soil sampling activities were carried out at the Sikundur monitoring station in Gunung Leuser National Park (Figure 1) on May-August 2019. The Sikundur monitoring station is located in Besitang Subdistrict, Langkat District, North Sumatra Province, Indonesia with an area of \pm 500 ha. Geographically, it is

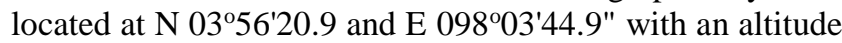
between 30-100 meters above sea level. The topographical conditions at Sikundur Monitoring station of GLNP are generally flat, with few areas are undulating and mild. The geological and soil consist of igneous and volcanic rock materials with brown to brownish podzolic soil (Sumatran Orang Utan Conservation Programme 2015).

\section{Data collection}

The data for vegetation analysis and floristic composition were collected by applying purposive sampling technique based on guided information and reports on the occurrence of $S$. macropodum in certain sites of the forest (Jumawan 2015; Rachmat et al. 2018). Species identification was carried out by employing a botanist. Few species unable to identify in the field were taken its specimens to be identified later in the herbarium.

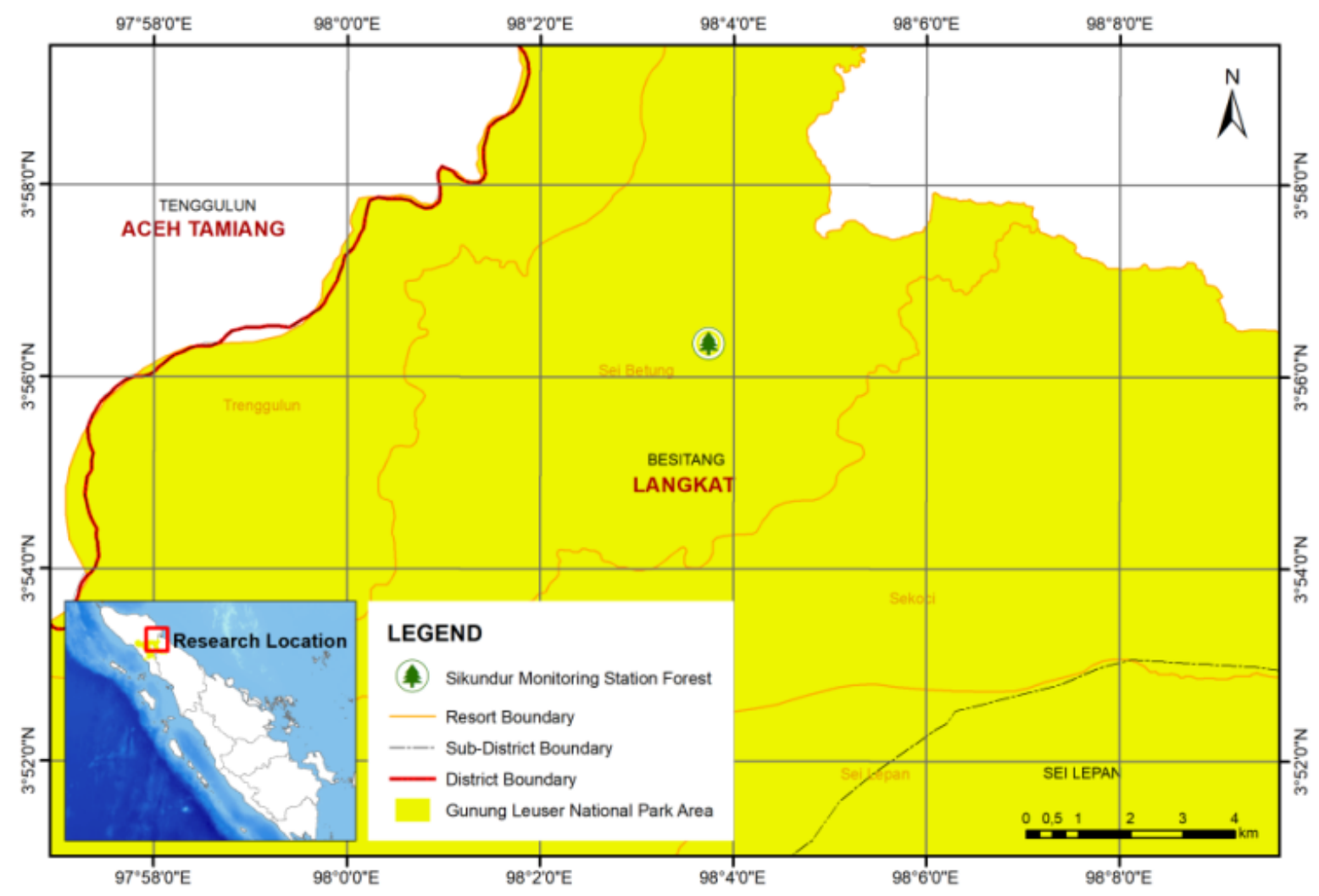

Figure 1. The study location at Sikundur monitoring station in Gunung Leuser National Park, Sumatra, Indonesia 
There were total of four transects established at the studied sites where $S$. macropodum grow, with five plots/quadrats for each transect. A line transect was established starting from the forest edge with the minimum length of transect was $200 \mathrm{~m}$. In each transect, nested plots were established with the size of $2 \times 2 \mathrm{~m}^{2}, 5 \times 5 \mathrm{~m}^{2}, 10 \times 10$ $\mathrm{m}^{2}$, and $20 \times 20 \mathrm{~m}^{2}$ to record all necessary data for seedling, sapling, pole, and tree stages, respectively. The observed variables for each stage were as follows: (i) Seedling stage (germinated seeds to $<1.5 \mathrm{~m}$ in height): species, number of individuals of each species; (ii) Sapling stage (height $>1.5$ $\mathrm{m}$ to diameter at breast height $(\mathrm{dbh})<10 \mathrm{~cm})$ : species, number of individuals of each species; (iii) Pole stage (10 $\mathrm{cm} \leq \mathrm{dbh}<20 \mathrm{~cm}$ ): species, dbh, height; (iv) Tree stage $(\mathrm{dbh}>20 \mathrm{~cm})$ : species, dbh, height. These data were then used to calculate relative density, frequency, abundance, and dominance of the tree species; and from those values, the Importance Value Index (IVI) was calculated.

\section{Data analysis}

To express the dominance and biological success of some species with a single value, the concept of Importance Value Index (IVI) has been developed by Curtis and McIntosh (1950), Phillips (1959), and Misra (1968). Rastogi (1999) and Sharma (2003) report IVI as a better expression of the relative ecological importance of a species than an absolute measure such as frequency, density, or dominance. IVI of each species was obtained by summing the relative value of three parameters, namely relative density $(R D)$, relative frequency $(R F)$, and relative dominance or relative basal area (RBA).

\section{Relative density}

Relative Density (RD) denotes the average number of individuals of a given species out of the total of samples examined in a study area (Oosting 1942; Rastogi 1999; Sharma 2003). It is calculated using the following formula:

$$
\mathrm{RD}=\frac{\text { Total number of individual of species }}{\text { Total number of all individual of all species }} \times 100 \%
$$

\section{Relative frequency}

Frequency indicates the number of sampling plots in which a given species occurs as a percentage of all sampling plots and is based on the presence or absence of a species (Rastogi 1999; Sharma 2003). It is calculated using the following formula:

$$
\mathrm{RF}=\frac{\text { Frequency of respective species }}{\text { Frequency of all species }} \times 100 \%
$$

\section{Relative basal area}

Dominance is defined as the sum of basal areas of all individuals of a species. Basal area refers to the ground covered by the stems (Rastogi 1999; Sharma 2003). Relative Basal Area (RBA) is calculated using the following formula:

$$
\text { RBA }=\quad \frac{\text { Basal area of a species }}{\text { Total basal area of all species }}
$$

Importance Value Index (IVI) (\%)

IVI can be calculated using the formula:

For tree species, IVI $=\mathrm{RD}+\mathrm{RF}+\mathrm{RBA}$

For seedlings and saplings, IVI $=\mathrm{RD}+\mathrm{RF}$

\section{Species diversity}

Various diversity measures are calculated by using Shannon-Wiener index $\left(\mathrm{H}^{\prime}\right)$, Margalef index $(\mathrm{R})$, and Evenness (E). The species diversity is determined by using Shannon-Wiener and is formulated as follows:

$$
\mathrm{H}^{\prime}=\sum \text { pi ln pi; }
$$

Where, pi is the proportion of individuals of ith species and individuals of all species in a stand. According to Indriani (2009), the Shannon-Weiner diversity index value criteria can be categorized as low $\left(\mathrm{H}^{\prime}<1\right)$, moderate $\left(\mathrm{H}^{\prime} 1\right.$ 3) and high ( $\left.\mathrm{H}^{\prime}>3\right)$.

The species richness $(\mathrm{R})$ is determined by using Margalef index and is calculated as follows:

$$
\mathrm{R}=\mathrm{S}-1 / \operatorname{Ln}(\mathrm{No})
$$

Where; $\mathrm{S}$ is the number of species in observed plot, where No is the total individual in observed plot.

The dispersion/distribution of individual is determined by using Evenness index (E) and is calculated as follows:

$$
E=S /\left(\log n_{i_{-}} \log n_{S}\right)
$$

Where; $\mathrm{S}$ is the number of species in observed plot, $\mathrm{n}_{\mathrm{i}}$ and $\mathrm{n}_{\mathrm{s}}$ are the density value of most and least important species, respectively. The dispersion of a species is categorized as low uniformity if $0<\mathrm{E}<0.5$ and high uniformity if $0.5<\mathrm{E}<1$.

\section{Species association}

Species association was generated by making contingency table $2 \times 2$ followed by chi quadrat test. For each pair of species A and B, we can obtain the following: $\mathrm{a}=$ the number of samples in which species $\mathrm{A}$ and $\mathrm{B}$ cooccurred; $b=$ the number of samples in which species $A$ occurs, but not $\mathrm{B}$; $\mathrm{c}=$ the number of samples in which species $B$ occurs, but not $A ; d=$ the number of samples in which neither A nor B are found; $\mathrm{N}=$ the total number of samples. Further, we tested for the Ochai Index. A positive association was determined where a> E (a) and negative association when $a<E(a)$. Association present if $x 2$ test $<x$ table, when $x$ table is 3.84 . Ochai Index test was used to show the association level, as the value approaches 1 , it showed maximum association (Ludwig and Reynold 1988).

\section{RESULTS AND DISCUSSION}

\section{Floristic composition at the habitat of $\boldsymbol{S}$. macropodum}

According to Okuda et al. (2013), the distribution of Scaphium species is strongly influenced by microhabitat heterogeneity, which is related to topography. Our research 
at Sikundur monitoring station found $S$. macropodum at all growth stages, i.e.: seedling, sapling, pole, and tree stages (Figure 2).

\section{Seedling stage}

The occurrence of seedlings is an important indicator of natural regeneration continuity. Of 80 plot of the seedling stage observation, there were 24 tree species with 272 individuals. Gonystylus macrophyllus was found as the species with the highest RD and IVI values followed by Scaphium macropodum. The ten highest IVI value trees were Gonystylus macrophyllus, Schapium macropodum, Dipterocarpus grandiflorus, Koompassia malaccensis, Cinnamomum cuspidatum, Nephelium cuspidatum, Hopea beccariana, Aromadendron sp., Ficus sp., and Myristica speciosa (Table 1). The high abundance and dominance of G. macrophyllus and S. macropodum at seedling stage may be caused by the light preference of both species.

Gonystylus macrophyllus or generally known as 'ramin' is one of commercially important timber species and currently classified into least concern status according to IUCN Redlist (Barstow 2018). This species is native to Malaya Peninsula, Borneo and Sumatra. The young trees require $90 \%$ of shading conditions while its adult trees need full sunlight (Partomiharjo et al. 2008). Direct sunlight can inhibit the growth of G. macrophyllus seedlings and cause pale leaves and deteriorated seedlings. The dense canopy with heavy shade from sunlight penetration created preferable environment for the dominancy of ramin seedlings in this area.

Scaphium macropodum is also known as a shadetolerant tree species and it is commonly found abundantly under closed canopies (Yamada and Suzuki 1997, Yamada et al. 1999). The young trees need closed canopy for their growth. S. macropodum produces fruits with a boat-shaped wing derived from a dehiscing follicle. The dispersal distance of the fruit rarely exceeds $50 \mathrm{~m}$ from the base of the parent tree (Yamada and Suzuki 1997). As a shadetolerant species, $S$. macropodum has a special physiological response named ontogeny as a form of adaptation to limited light environment. D. grandiflorus ranked $3^{\text {rd }}$ in terms of IVI. This species is commonly targeted by illegal logging, making it as endangered species according to IUCN (Ly et al. 2017). Beside utilized for its timber, $D$. grandiflorus also produce resin to be used as illuminant to varnish and caulk boats.

\section{Sapling stage}

At sapling stage, 35 tree species with 173 individuals were found. Scaphium. macropodum was the most dominant species, indicated by the highest RD, RF, and IVI values, then followed by Pimelodendron sp., Cinnamomum cuspidatum, Casuarina equisetifolia, Aromadendron sp, Endospermum diadeum, Myristica speciosa, Hopea beccariana, Callophylum sp. and Syzygium malaccensis (Table 2). Interestingly, Gonystilus macrophyllus was excluded from top ten ranks. It may be caused by the substantial increase in light requirement from $90 \%$ shade (seedling stage) to $30-65 \%$ shade at sapling stage (Muin and Purwita, 2002). Light is critical delimitation for some light-demanding-species. The presence of local light variation may influence the growth and abundance of herbaceous layer, young trees, and seedling (Smith and Berry 2013).

Table 1. The top ten species with the highest important value index (IVI) at seedling stage

\begin{tabular}{lllll}
\hline Rank & Species & RD & RF & IVI \\
\hline 1 & Gonystylus macrophyllus & 25.00 & 16.07 & 41.07 \\
2 & Scaphium macropodum & 23.53 & 16.07 & 39.60 \\
3 & Dipterocarpus. grandiflorus & 7.35 & 8.93 & 16.28 \\
4 & Koompassia malaccensis & 9.19 & 1.79 & 10.98 \\
5 & Cinnamomum cuspidatum & 5.15 & 5.36 & 10.50 \\
6 & Nephelium cuspidatum & 3.31 & 5.36 & 8.67 \\
7 & Hopea beccariana & 3.31 & 5.36 & 8.67 \\
8 & Aromadendron sp. & 2.21 & 5.36 & 7.56 \\
9 & Ficus sp. & 2.57 & 3.57 & 6.14 \\
10 & Myristica speciosa & 1.84 & 3.57 & 5.41 \\
\hline
\end{tabular}

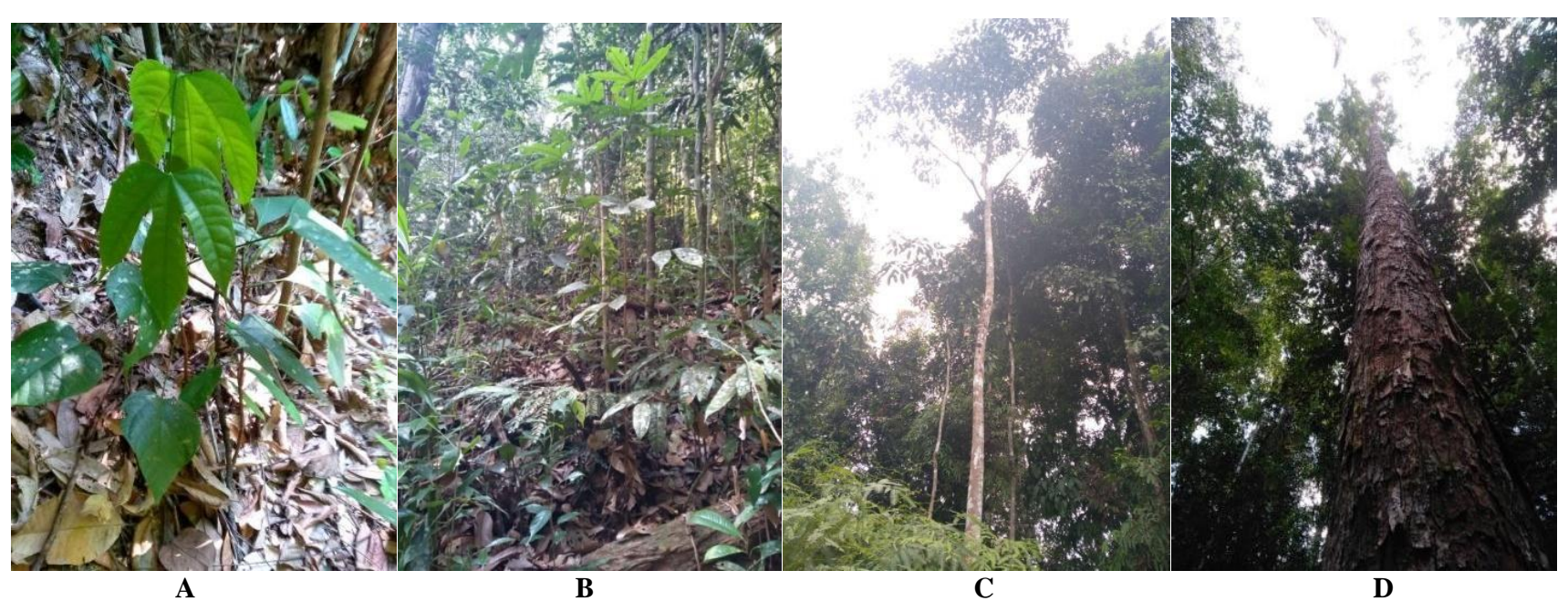

Figure 2. Scaphium macropodum at Sekundur monitoring station, Gunung Leuser National Park, Sumatra, Indonesia at different growth stage: A. Seedlings, B. Saplings, C. Poles, D. Trees 
Table 2. The top ten species with the highest important value index (IVI) at sapling stage.

\begin{tabular}{lllll}
\hline Rank & Species & RD & RF & IVI \\
\hline 1 & Scaphium macropodum & 15.61 & 11.69 & 27.30 \\
2 & Pimelodendron sp. & 9.25 & 9.09 & 18.34 \\
3 & Cinnamomum cuspidatum & 8.09 & 7.79 & 15.88 \\
4 & Casuarina euisetifolia & 7.51 & 6.49 & 14.01 \\
5 & Aromadendron sp. & 8.09 & 3.90 & 11.99 \\
6 & Endospermum diadeum & 6.93 & 3.90 & 10.83 \\
7 & Myristica speciosa & 4.04 & 3.90 & 7.94 \\
8 & Hopea beccariana & 4.62 & 2.60 & 7.22 \\
9 & Callophylum sp. & 2.89 & 3.90 & 6.79 \\
10 & Syzygium malaccensis & 2.31 & 3.90 & 6.21 \\
\hline
\end{tabular}

\section{Pole stage}

Scaphium macropodum ranked $3^{\text {nd }}$ in terms of IVI among 56 species at pole stage (Table 3). Species with the highest IVI was Gonystylus macrophyllus. At both sapling and tree stages, G. macrophyllus were the not dominant species, however, at the pole stage, it is showed that these species gain its dominancy by having the highest IVI. The occurrence of habitat changes and disturbance along the transects at the sapling and tree stages may have become the cause for the low dominance of G. macrophyllus in the area. Seedling population at logged over area is found to be low (Sutisna et al. 1988), despite the initial population before the timber extraction was high. A previous study showed that regeneration pattern of ramin seemed interesting in which the seedling that was initially abundant was drastically reduced in further stages (Trimanto and Sofiah 2018; Partomiharjo et al. 2008). Another previous study conducted by showed almost similar results where ramin seedlings were present in large quantities in early stages, but they disappeared at sapling stage. However, different phenomenon was found in this study located in GLNP in which it was observed that ramin dominated the pole stage with the highest IVI value.

The high abundance of ramin at the seedling stage may be the result of recent fruiting season with the seeds had grown into seedlings. However, high disturbances resulted from environmental factors (e.g. gap openness) and humans' activities (e.g. timber and non-timber forest product extraction) had likely caused ramin seedlings fail to survive and to grow into sapling stage. While ramin relisted in the top five highest IVI at pole stage, this might be considered as the remnant individuals that had already existed earlier when human disturbance/intervention in this area was less intensive. The level of human interference to ramin disturbance at the pole stage seems to be more insensitive compared to sapling stage. Habitat changes caused by human activity were still in the tolerance range of ramin pole to survive and even it was still able to dominate the area. The level of disturbance has an impact on plant diversity. This condition is in accordance with the research of Sutisna et al. (1988) stating that the population of ramin has generally been much lower at disturbed areas, although previously in the same forest area their population was quite high. Both of natural and man-made activities have influenced species diversity, vegetation structure, and natural regeneration of a forest ecosystem.

\section{Tree stage}

At tree stage, Koompassia malaccensis had the highest IVI and RD values (Table 4). Scaphium macropodum ranked second in IVI value while in the dominance it ranked third of 57 species. Vegetation with high IVI does not always have high-density value as density value indicates the level of species in covering an area. This result suggests that ecologically the growth of Scaphium macropodum is better at the tree stage. The population of $S$. macropodum was quite abundant, although its dominance was lower than Koompassia malaccensis and Alseodaphne macrocarpa. The competition among species in a forest will result in natural selection and may decrease the dominance of a species. According to Huy (2012), S. macropodum population will decrease in the presence of disturbance and dominant species invasion.

At the tree stage, G. macrophyllus was not listed as one of the top five ranks. The absence of G. macrophyllus at the tree stage may be caused by timber extraction. The pattern of G. macrophyllus structure and composition in the study area was very susceptible and may act as an indicator of the problem in their natural regeneration and the existence of high disturbance. Pala et al. (2012) state that successful regeneration of a tree species can be predicted by the structure of their overall populations as well as sufficient numbers of seedlings, saplings, and adults.

Table 3. The top ten species with the highest important value index (IVI) at pole stage

\begin{tabular}{lllll}
\hline Rank & Species & RD & RF & RBA \\
\hline 1 & Gonystylus macrophyllus & 9.52 & 4.96 & 9.78 \\
2 & Cinnamomum cuspidatum & 4.76 & 3.31 & 7.00 \\
3 & Scaphium macropodum & 4.17 & 4.96 & 4.73 \\
4 & Dipterocarpus sp.. & 5.36 & 4.13 & 4.34 \\
5 & Pithecellobium jiringa & 4.17 & 3.31 & 4.18 \\
6 & Archidendron bubalinum & 0.44 & 3.31 & 7.85 \\
7 & Sapium baccatum & 3.57 & 3.33 & 3.18 \\
8 & Myristica speciosa & 2.98 & 3.33 & 11.65 \\
9 & Litsea sp. & 1.79 & 2.50 & 1.4 \\
10 & Baccaurea motleyana & 2.98 & 1.67 & 1.82 \\
\end{tabular}


Table 4. The top ten species with the highest important value index (IVI) at tree stage

\begin{tabular}{llllll}
\hline Rank & Species & RD & RF & RBA & IVI \\
\hline 1 & Koompassia malaccensis & 4.27 & 3.03 & 18.56 & 25.86 \\
2 & Scaphium macropodum & 7.69 & 8.08 & 6.21 & 21.98 \\
3 & Alseodaphne macrocarpa & 5.13 & 4.04 & 8.00 & 17.17 \\
4 & Sapium baccatum & 5.13 & 4.04 & 2.63 & 11.80 \\
5 & Cinnamomum cuspidatum & 4.27 & 4.04 & 3.47 & 11.78 \\
6 & Endospermum diadeum & 4.27 & 4.04 & 1.93 & 10.25 \\
7 & Pimelodendron griffithianum & 2.56 & 2.02 & 4.92 & 9.51 \\
8 & Litsea sp. & 3.42 & 3.03 & 1.90 & 8.34 \\
9 & Dipterocarpus grandiflorus & 0.85 & 1.01 & 6.11 & 7.97 \\
10 & Durio griffithii & 2.56 & 2.02 & 3.18 & 7.77 \\
\hline
\end{tabular}

Table 5. Diversity, evenness, and species richness index for species at Scaphium macropodum habitat

\begin{tabular}{lcccc}
\hline $\begin{array}{c}\text { Plant } \\
\text { stage }\end{array}$ & $\begin{array}{c}\text { Species } \\
\text { diversity } \\
(\mathbf{H})\end{array}$ & $\begin{array}{c}\text { Evenness } \\
\text { index } \\
(\mathbf{E})\end{array}$ & $\begin{array}{c}\text { Species } \\
\text { richness } \\
\text { index }(\mathbf{R})\end{array}$ & $\begin{array}{c}\text { Number of } \\
\text { species }\end{array}$ \\
\hline Seedling & 2.45 & 0.77 & 4,10 & 24 \\
Sapling & 3.06 & 0.86 & 6.59 & 35 \\
Pole & 3.70 & 0.92 & 10.73 & 56 \\
Tree & 3.80 & 0.94 & 11.76 & 57 \\
\hline
\end{tabular}

The loss of some species in tree stage might be caused by some human activities such as illegal logging. According to Sumatran Orang Utan Conservation Programme (2015), The Sikundur area, previously the Sikundur Reserve (est. 1938) prior to the formation of the TNGL (est. 1980) was selectively logged starting in the late 1960s, which continued and progressively intensified in some areas until the 1980s (Wind, 1996). Following the establishment of the TNGL, logging in the Sikundur area continued primarily at the park border. Currently, illegal logging and in some cases complete land clearing is still present near the southeastern boundary of the Sikundur Monitoring Post at the TNGL border, in addition to more generalized illegal human extractive activities (e.g., bird trapping, damar resin extraction, and fishing).

In our research plot, $S$. macropodum individuals were found at every growth stage with $2^{\text {nd }}$ rank, $1^{\text {st }}$ rank, $3^{\text {th }}$ rank, and $2^{\text {nd }}$ rank on seedling, sapling, pole, and tree stage, respectively. The abundance of $S$. macropodum in our location might be caused by its shade-tolerant characteristic. The number of species on every growth stage was fluctuating. According to Saniga and Balanda (2008), the floristic composition of a forest reflects the complex ecological conditions of a particular site. In natural forests, the composition is heterogeneous, resulted from relationships among different ecological requirements of individuals of tree species, as well as the different growth capabilities and different physical ages of each species that they could reach. The nature of forest communities largely depends on the ecological characteristics of the sites, species diversity, and regeneration status of tree species in a community. The species and floristic composition are the key significance to understanding the form and structure of a forest community and also for planning and implementation of conservation strategies of the community (Malik 2014).

\section{Species diversity}

Species diversity was quantified using three components: richness, evenness, and disparity. The value of species diversity indices on our research plot showed that in tree stage is higher than that of in saplings and seedlings stage (Table 5). The highest Shanon-Wiener diversity index $\left(\mathrm{H}^{\prime}=3.80\right)$ was found at the tree stage (3.80), followed by pole stage (3.70). The values for this index are generally between 1.5 and 3.5 in most ecological studies, and the index is rarely higher than 4 . The ShannonWiener index increases as both the richness and the evenness of the community increase. The study result showed that from all stages (from seedling to tree stages), Shannon-Wiener indices ranged of 2.45-3.80. It indicates that tree stage had the highest value in both species richness and evenness, resulted in higher Shannon-Wiener index than other stages. According to Arijani (2008), if certain species are dominant in a location while the others are not dominant or have lower density, the value of the species diversity is lower compared to a more uniformity site.

The equitability of a community's species abundance distribution is referred to as its evenness and in numerical sense and ranges between 0 and 1 . A community is perfectly even if every species is present in equal proportion, and uneven if one species dominates the abundance distribution. The species evenness index in this research ranged from $0.77-0.94$. If a community has a large disparity between the numbers of individuals within each species, it has low evenness. If the number of individuals within a species is fairly constant throughout the communities it has high evenness. The results of the study demonstrated that at most stage the evenness value was high.

The species richness defines as the absolute number of species present in the population of interest (Aisling et al. 2018). The species richness and diversity of trees are fundamental to total forest biodiversity, because trees provide resources and habitat for almost all other forest species (Malik 2014). The decrease in species richness over time is attributable to age-dependent local extinction of short-lived, early-successional, shade-intolerant species 
(Chen and Popadiouk 2002; Luo and Chen 2011). The index of species richness ranged from 4.10 to 11.76 . Based on the species richness value, the tree stage had the highest value of species richness, indicating that at tree stage the species variation is higher than the others. The larger the number of species, but lower number of individuals, then the greater the richness index is. The variation in species richness and diversity for both tree species and seedlings can be attributed to the habitat heterogeneity represented by soil chemical properties (Myklestad, 2004), environmental factors (Tilk et al. 2017), and human disturbance (Biswas and Mallik, 2010). According to Huy (2012), the presence of disturbance and dominant species invasion will decrease species diversity and abundance. Pala et al. (2012) state that successful regeneration of a tree species can be predicted by the structure of their overall populations as well as sufficient numbers of seedlings, saplings, and adults.

\section{Species association}

Association study was conducted to determine what relationship occurs between $S$. macropodum with certain species within the community (Table 6). This information is important to conserve $S$. macropudum in the future. A negative association pattern between two species might be as result of competition or differences in habitat preference (Rachmat et al. 2018) while a positive pattern might be the result of facilitation or neutrality and similarity in habitat preference (Kent and Coker 1992).

From the association analysis, it showed that there were only two positive associations, that $S$. macropodum with $E$. diadenum and $C$. cuspidatum. The pattern of positive association between species is common in tropical and subtropical forests (Ledo, 2015). Several studies showed similar result such as tropical forest tree species of Eusideroxylon zwageri and Shorea leprosula and Ficus albipila (Sari and Maharani, 2016) and Dipterocarpus cinereus with Arenga pinnata (Rachmat et al. 2018). In ideal condition when anthropogenic and natural disasters may be neglected, positive association may be simply translated as the occurrence of one species will be followed by the finding of its pair. Various direct and direct factors or mechanisms both biotic and abiotic may be the cause for the pattern of positive and negative associations between species. Positive association between two species or so called spatial attraction may happen due to similar common requirements such as the need of light intensity, reaction to particular disturbance, soil nutrient, and the occurrence of a second facilitative agent of mycorrhizae (Uriarte et al. 2012, John et al. 2007, Kitajima et al. 2005). However, when artificial disturbances to the habitat caused by human activity, association pattern may not be reflected in the actual condition of the established association.

Our research found that GLNP experiences human disturbance such as land conversion into agricultural purpose and settlements. Another research conducted by Pandiangan et al. (2017) also found that the core and wilderness zones in GLNP contain a land cover of plantations, cropland, settlements, and paddy fields. This means these zones are no longer in pristine condition and without any human interference. In Sikundur forest station, Sumatran Orang Utan Conservation Programme (2015), stated that human intervention through illegal logging and in some cases complete land clearing are still present in this location. This condition will cause association patterns not reflected the actual condition.

\section{Conservation action}

Scaphium macropodum or its fruit is globally known as malva nut has been economically attractive for community livelihood surrounding the forest. However uncontrolled harvesting of malva nut (Huy et al. 2012) which entailed the felling of trees as form of destructive harvesting, lower natural regeneration (Priatna et al. 2006) and loss of mature trees has become the major cause of population decline in the wild (World Conservation Monitoring Center 1998). Even at the national park that has the highest level of protection (Poor et al. 2019), the anthropogenic alteration to the species are still be found (Pandiangan et al. 2017; Sumatran Orang Utan Conservation Programme 2015) and it has been worsened for those at the forest that is not under the criteria of protected area. Related to the conservation of the species, there are several ways that can be considered to take in action. There should be formation and training to the community on sustainable techniques for harvesting malva nut. Government as the regulator should start paying attention more to the commodity by developing a permit system to assure non-destructive harvesting practiced within community. The harvester community should also be linked with companies to improve and keep stable prices. By these activities, it is considered that income from malva nut collection shall be improved and that could lessen the significant decrease in their illegal destructive harvesting. The key important step that could be initiated as soon as possible is the domestication of the species since there is no malva nut product harvested from the garden until today. All the nuts originated from the extraction in the wild. Knowledge on silvicultural and cultivation techniques should receive more concern. The culture of what you plant is what you harvest must be practiced sooner unless there is nothing to leave for future generations.

Table 6. Association between Scaphium macropodum and other dominant tree species

\begin{tabular}{lllcc}
\hline \multicolumn{1}{c}{ Species } & a & b & c & Assoc. index \\
\hline S. macropodum with E. diadenum & 4 & 4 & 0 & 0.707 \\
S. macropodum with C. cuspidatum & 4 & 4 & 0 & 0.707 \\
S. macropodum with C. baccatum & 3 & 5 & 0 & 0.612 \\
S. macropodum with Litsea sp. & 3 & 5 & 0 & 0.612 \\
S. macropodum with A. macrocarpa & 3 & 4 & 1 & 0.567 \\
\hline
\end{tabular}




\section{ACKNOWLEDGEMENTS}

This research was supported by Universitas Sumatera Utara, Medan, Indonesia (USU) through TALENTA Research Grant scheme for Basic Research (PD) number 273/UN5.2.3.1/PPM/KP-TALENTA USU/2019. Great appreciation and gratitude are also addressed to Gunung Leuser National Park for the research permit.

\section{REFERENCES}

Ai L, Wu J, Na C. 2012. Extraction, partial characterization and bioactivity of polysaccharide from boat-fruited Sterculia seeds. Int J Biol Macromol 51: 815-818

Aisling JD, Baeten JM, Baet BD. 2018. Ecological diversity: measuring the unmeasurable. Mathematics 6 (119): 1-28

Arijani A. 2008. Vegetation structure and composition of the montane zone of Mount Gede Pangrango National Park. Biodiversitas 9 (2): 134-141.

Bann C. 1997. Economic analysis of tropical forest land use options, Ratanakiri Province, Cambodia. EEPSEA research report series/IDRC. Economy and Environment Program for Southeast Asia.

Barstow M. 2018. Gonystylus macrophyllus. The IUCN Red List of Threatened Species 2018. DOI: 10.2305/IUCN.UK.20181.RLTS.T33226A68085123.en

Biswas SR, Mallik AU. 2010. Disturbance effects on species diversity and functional diversity in riparian and upland plant communities. Ecology 91 (1): 28-35

Chen HYH, Popadiouk RV. 2002. Dynamics of North American boreal mixed woods. Environ Rev 10: 137-166.

Dhage P, Kasture SB, Mohan M. 2015. Analgesic, anti-inflammatory, antioxidant and antiulcer activity of ethanolic extract of Sterculia scaphigera Hance (Sterculiaceae) seeds in mice and rats. Intl J Biol Pharm Res 4 (1): 35-45.

Dutta G, Devi A. 2013. Plant diversity, population structure, and regeneration status in disturbed tropical forests in Assam, northeast India. J For Res 24 (4): 715-720.

Huy LQ, Werger MJA, Boot RGA, Nghia NH. 2012. Species Diversity Analysis of Tree Plant Community in Scaphium macropodum Forest Under Different Levels of Disturbance. Growth, Demography and Stand Structure of Scaphium macropodum in Differently Managed Forests in Vietnam. [Disertation]. Utrecht University, Nederlands.

John R, Dalling JW, Harms KE, Yavitt JB, Stallard RF, Mirabello M, et al. 2007. Soil nutrients influence spatial distributions of tropical tree species. Proc Natl Acad Sci USA 104: 864-869.

Jumawan J, Flores FL, Aragan RT, Villamar JMC, Sagut JS, Taguse HC, Genecera J, Banas GG, Depamaylo AMV. 2015. Diversity assessmen and spatial structure of mangrove community in a rehabilitated landscape in Hagonay, Davao Del Sur, Philippines. Adv Environ Sci Bioflux 7 (3): 475-482.

Kitajima K, Mulkey SS, Wright SJ. 2005. Variation in crown light utilization characteristics among tropical canopy trees. Ann Bot 95: 535-547.

Ledo A. 2015. Nature and Age of Neighbours Matter: Interspecific Associations among tree species exist and vary across life stages in tropical forests. PLoS ONE 10 (11): e0141387. DOI: 10.1371/journal.pone.0141387.

Li C. 2015. Sterculia lychnophora Hance (Pangdahai, Malva Nut Tree) In: Liu Y, Wang Z, Zhang J. (eds) Dietary Chinese Herbs. Springer, Vienna.

Lim TK. 2012. Edible Medicinal and Non-Medicinal Plants. Springer Dordrecht, The Netherlands.

Luo Y, Chen HYH. 2011. Competition, species interaction and ageing control tree mortality in boreal forests. J Ecol 99: 1470-1480.

Magurran AE. 2004. Measuring Biological Diversity. Blackwell, UK.

Malik ZA, Pandey R, Bhatt AB. 2016. Anthropogenic disturbances and their impact on vegetation in Western Himalaya, India. J Mountain Sci 13: 69-82.

Misra R. 1968. Ecology Work Book. Oxford and IBH, Calcutta.
Muin A, Purwita T. 2002. Light intensity for maintenance of natural regeneration and planting of ramin (Gonystylus bancanus (Miq.) Kurz) in the former logged area HPH PT Munsin dan Inhutani II. Majalah Kehutanan Indonesia 6: 9-13. [Indonesian]

Myklestad, A2004. Soil, site and management components of variation in species composition of agricultural grasslands in western Norway. Grass Forage Sci 59: 136-143.

Ogale SC, Kasture SB, Kasture VS. 2015. Screening of methanolic extract of Sterculia scaphigera seeds for ulcer protective and antioxidant activity. World J Pharm Pharm Sci 4 (1): 1332-46.

Okuda T, Manokaran N, Matsumoto Y, Niiyama K, Thomas SC, Ashton PS. 2013. Pasoh: ecology of a lowland rain forest in Southeast Asia. Springer Science \& Business Media, Nederlands.

Oostig HJ. 1942. An ecological analysis of the plant communities of Piedmont, North Carolina. Am Midl Nat 28: 1-126.

Pandiangan E, Ardhiyansah M, Rusdiana O. 2017. Analysis of change in land cover to support the management of Gunung Leuser National Park. J Regional City Planning 28 (2): 81-98.

Partomihardjo T, Prajadinata, S, Hidayat A. 2008. Current Status of Ramin Seeds Source in Sumatra. Technical Report ITTO PROJECT PO 426/06 Rev. 1 (F). Indonesian Ministry of Forestry, Jakarta.

Phillips EA. 1959. Methods of vegetation study. Henry Holt. \& Co., Inc. New York.Phonesena P and Wilkie P. 2008. Scaphium affine (Mast.) Pierre (Sterculiaceae) new for Thailand. Thai For Bull (Bot) 36: 61-9.

Poor EE, Jati VIM, Imron MA, Kelly MJ. 2019. The road to deforestation: Edge effects in an endemic ecosystem in Sumatra, Indonesia. PLoS ONE 14 (7): e0217540. DOI: 10.1371/journal.pone.0217540.

Priatna D, Kartawinata K, Abdulhadi K. 2006. Recovery of a lowland dipterocarp forest twenty-two years after selective logging at Sekundur, Gunung Leuser National Park, North Sumatra, Indonesia. Reinwardtia 12 (3): 237-255.

Rachmat HH, Subiakto A, Wijaya K, Susilowati A. 2018. Alarming call from Mursala Island, North Sumatra: The urgent task of conserving the previously reported extinct of Dipterocarpus cinereus. Biodiversitas 19 (2): 399-405.

Rastogi A. 1999. Methods in Applied Ethnobotany: Lesson from the Field. Kathmandu, Nepal. International Center for Integrated Mountain Development (ICIMOD). Kathmandu, Nepal.

Sambas ED, Siregar M. 2017. Floristic and Forest Structural Study in Batangtoru Watershed, North Sumatra (Studi Floristik dan Struktur Hutan di Daerah Aliran Sungai Batangtoru, Sumatera Utara). Jurnal Biologi Indonesia 13 (1): 21-31. [Indonesian]

Sharma PD. 2003. Ecology and Environment. 7th ed. Rastogi Publication, New Delhi.

Smith WK, Berry ZC. 2013. Sunflecks? Tree Physiol 33: 233-237.

Sumatran Orang Utan Conservation Programme. 2015. Sikundur Monitoring Post. Annual Report 2015. Sumatran Orang Utan Conservation Programme, Medan

Susilowati A, Rachmat HH, Elfiati D, Hasibuan MH. 2019. The composition and diversity of plant species in pasak bumi's (Eurycoma longifolia) habitat in Batang Lubu Sutam forest, North Sumatra, Indonesia. Biodiversitas 2 (20): 413-418.

Sutisna UH, Soeyatman C, Wardani M. 1988. Analysis of composition of Tangkiling and Sampit peat swamp forest tree species. Central Kalimantan. Bul. Penelitian Hutan No. 497: 4156.

Trimanto, Sofiah S. 2018. Exploration of flora diversity and recommending species for reclamation of coal mining with biodiversity concept in Besiq Bermai Forest, East Borneo. J Trop Life Sci 8 (2): 97-107.

Tilk M, Tulus T, Ots K. 2017. Effects of environmental factors on the species richness, composition and community horizontal structure of vascular plants in Scots pine forests on red sand dunes. Sylva Fennica 52 (3): 1-18.

Uriarte M, Clark JS, Zimmerman JK, Comita LS, Forero-Montaña J, Thompson J. 2012. Multidimensional trade-offs in species responses to disturbance: implications for diversity in a subtropical forest.Ecology 93: 191-205.

Wilkie P. 2009. A revision of Scaphium (Sterculioideae, Malvaceae Sterculiaceae) Edinburgh. J Bot 66: 283-328.

Wind, J. 1996. Gunung Leuser National Park: History threats, and options. In: van Schaik C and Supriatna J (eds.), Leuser: A Sumatran Sanctuary. Yayasan Bina Sains Hayati Indonesia, Indonesia.

World Conservation Monitoring Centre. 1998. Scaphium macropodum. The IUCN Red List of Threatened Species 1998: e.T33255A9771604. DOI: 10.2305/IUCN.UK.1998.RLTS.T33255A9771604.en 
Yamada T, Suzuki E. 1996. Ontogenic change in leaf shape and crown form of a tropical tree species, Scaphium macropodum (Sterculiaceae) in Borneo. J Plant Res 109: 2l-217.

Yamada T, Suzuki E. 1997. Change in spatial distribution during the life history of a tropical tree species, Scaphium macropodum (Sterculiaceae) in Borneo. J Plant Res 110: 179-186.
Yamada T, Akira Itoh A, Takuo MZ, Yamakura T, Suzuki E, Ashton PS. 2000. Local and geographical distributions for a tropical tree genus, Scaphium (Sterculiaceae) in the Far East. Plant Ecol 148: 23-30. 